\title{
New structural scaffold 14-membered macrocyclic lactone ring for selective inhibitors of cell wall peptidoglycan biosynthesis in Staphylococcus aureus
}

The Journal of Antibiotics (2013) 66, 303-304; doi:10.1038/ja.2012.122; published online 23 January 2013

During our screening program to search for new antibiotics effective against methicillinresistant Staphylococcus aureus (MRSA), ${ }^{1,2}$ albocycline, previously reported as an antibiotic active against staphylococci, ${ }^{3-6}$ was isolated from the fermentation broth of Streptomyces sp. 6-31, which was originally isolated from a soil sample collected at Hegurajima Island, Ishikawa, Japan. The compound has a 14-membered macrocyclic ring lacking any sugar moiety (Figure 1a). In a paper disk assay, the compound potently inhibited the growth of $S$. aureus including clinically isolated MRSA, whereas it did not affect other gram-positive and gram-negative bacteria, nor fungi (Bacillus subtilis, Micrococcus luteus, Mycobacterium smegmatis, Esherichia coli, Xanthomonas campestris, Pseudomonas aeruginosa, Mucor racemosus and Candida albicans). The antimicrobial activity of albocycline was selective towards S. aureus, which was in good agreement with the previous study. ${ }^{3}$ Furthermore, albocycline inhibited the growth of MRSA with an MIC value of $0.5-1.0 \mu \mathrm{g} \mathrm{ml}^{-1}$ in a microdilution assay, which represented the same potency as vancomycin. On the other hand, structurally related 14-membered erythronolide B (Figure 1a), erythromycin aglycone, was not active against MRSA (MIC value, $\left.>100 \mu \mathrm{g} \mathrm{ml}^{-1}\right)$. It was suggested that differences in modification of the 14-membered lactone rings yielded different activity against MRSA. Interestingly, there have been few reports on antibiotics selectively active against $S$. aureus. ${ }^{7}$ These findings prompted us to study the mechanism of action of albocycline active against $S$. aureus. Wholecell labeling experiments were carried out by investigating the incorporation of radioactive precursors $\left(\left[{ }^{3} \mathrm{H}\right]\right.$ thymidine, $\left[{ }^{3} \mathrm{H}\right]$ uracil, $\left[{ }^{3} \mathrm{H}\right]$ leucine and $\left.\left[{ }^{3} \mathrm{H}\right] \mathrm{GlcNAc}\right)$ into corresponding macromolecules using intact MRSA. ${ }^{8}$ The compound selectively inhibited the incorporation of $\left[{ }^{3} \mathrm{H}\right] \mathrm{GlcNAc}$ into macromolecules at $50.0 \mu \mathrm{g} \mathrm{ml}^{-1}$, suggesting that albocycline blocked the biosynthesis of cell wall peptidoglycan (Figure 1b). Furthermore, the synthesis of peptidoglycan was dose dependently inhibited by albocycline with an $\mathrm{IC}_{50}$ value of $34.5 \mu \mathrm{g} \mathrm{ml}^{-1}$. These results indicated that albocycline affected the biosynthesis of peptidoglycan of MRSA. In 1969, Reusser, F. ${ }^{9}$ reported that albocycline acted on the nicotinate biosynthesis in B. subtilis, resulting in the antimicrobial activity. However, albocycline showed no antimicrobial activity against B. subtilis in our study as well as in the previous study. ${ }^{3}$
In conclusion, we demonstrated that albocycline is an antibiotic selectively active against $S$. aureus by inhibiting the peptidoglycan biosynthesis. Macrolide antibiotics are reported to show various biological activities including their antibacterial and antiinflammatory properties, the attenuation of bacterial virulence factors and the stimulation of peristalsis. ${ }^{10}$ It is well known that the antibacterial activity is due to the inhibition of bacterial protein synthesis. The mechanism of action of albocycline is different from that of representative macrolide antibiotics. The structure of a 14-membered macrocyclic ring is not seen in known inhibitors of cell wall. Accordingly, the core structure is expected to provide a new structural scaffold for selective inhibitors of cell wall in<smiles>CO[C@H]1/C=C/[C@@](C)(O)/C=C/C(=O)O[C@@H](C)[C@@H]1C</smiles>

Albocycline

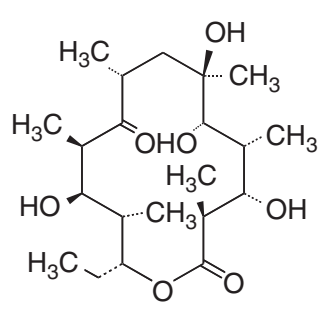

Erythronolide B

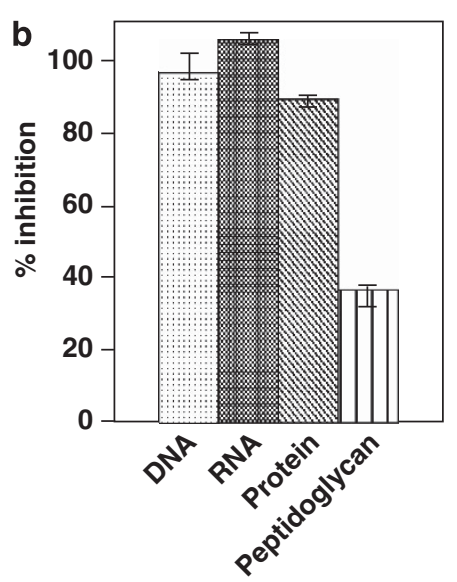

Figure 1 (a) Structures of albocycline and erythronolide B. (b) Whole-cell labeling experiments of albocycline. The inhibitory effects were determined by measuring incorporation of radioactive precursors of either DNA ( $\left[{ }^{3} \mathrm{H}\right]$ thymidine), RNA $\left(\left[{ }^{3} \mathrm{H}\right]\right.$ uracil), protein $\left(\left[{ }^{3} \mathrm{H}\right]\right.$ leucine) or peptidoglycan $\left(\left[{ }^{3} \mathrm{H}\right] \mathrm{Gl} \mathrm{CNAC}\right)$ synthesis in MRSA. The experiments were performed in the presence and absence of albocycline $\left(50 \mu \mathrm{g} \mathrm{ml}^{-1}\right)$. The percent inhibition was calculated as (1-(cpm in the presence of albocycline/cpm in the absence of albocycline) $) \times 100$. All values represent the average of three independent experiments. 
S. aureus, leading to the development of new anti-infectious agents against MRSA. The inhibition site remains to be identified.

\section{ACKNOWLEDGEMENTS}

This study was supported in part by grants from Kakenhis 21310146 (to H T) and 23790020

(to N K) from the Ministry of Education, Culture, Sports, Science and Technology of Japan, the Uehara Memorial Foundation (to H T), and a Kitasato University Research Grant for Young Researchers (to N K).

\section{Nobuhiro Koyama ${ }^{1}$, Makoto Yotsumoto ${ }^{1}$ Hiroyasu Onaka ${ }^{2}$ and Hiroshi Tomoda ${ }^{1}$}

${ }^{1}$ Graduate School of Pharmaceutical Sciences, Kitasato University, Minato-ku, Tokyo, Japan and
${ }^{2}$ Department of Biotechnology, Faculty of Engineering, Toyama Prefectural University, Imizu, Toyama, Japan

E-mail: tomodah@pharm.kitasato-u.ac.jp

1 Uchida, R. et al. Nosokomycins, new antibiotics discovered in an in vivo-mimic infection model using silkworm larvae. I: fermentation, isolation and biological properties. J. Antibiot. 63, 151-155 (2010).

2 Koyama, $\mathrm{N}$. et al. The nonantibiotic small molecule cyslabdan enhances the potency of $\beta$-lactams against MRSA by inhibiting pentaglycine interpeptide bridge synthesis. PLoS ONE 7, e48981 (2012).

3 Nagahama, N., Suzuki, M., Awataguchi, S. \& Okuda, T. Studies on a new antibiotic, albocycline. I. isolation, purification and properties. J. Antibiot. 20, 261-266 (1967).

4 Furumai, T., Nagahama, N. \& Okuda, T. Studies on new antibiotic, albocycline. II. Taxonomic studies on albocycline-producing strains. J. Antibiot. 21, 85-90 (1968).

5 Thomas, R. C. \& Chidester, C. G. Albocycline: structure determination by $\mathrm{X}$-ray crystallography. J. Antibiot. 35 1658-1664 (1982).

6 Harada, K., Nishida, F., Takagi, H., Suzuki, M. \& Iwashita, T. Studies on an antibiotic, albocycline VII. Minor components of albocycline. J. Antibiot. 37, 1187-1197 (1984)

7 Lee, J.-Y., Jeong, K.-W., Shin, S., Lee, J.-U. \& Kim, Y. Discovery of novel selective inhibitors of Staphylococcus aureus $\beta$-ketoacyl acyl carrier protein synthase III. Eur. J. Med. Chem. 47, 261-269 (2012).

8 Huber, J. et al. Chemical genetic identification of peptidoglycan inhibitors potentiating carbapenem activity against methicillin-resistant. Staphylococcus aureus. Chem. Biol. 16, 837-848 (2009).

9 Reusser, F. Mode of action of albocycline, an inhibito of nicotinate biosynthesis. J. Bacteriol. 100, 11-13 (1969).

10 Sunazuka, T. Novel action of macrolide antibiotics. Japanese Journal of Chemotherapy 52, 367-370 (2004) 